\title{
Voluntary Disclosure of Intellectual Capital: The Case Of Family And Non- Family Businesses In Jordan
}

\author{
Dr- Nahed Habis Alrawashedh - Amman Arab University - Business faculty \\ Dr- Laith Abelhaleem Khaddam -Applied Science Private University \\ Prof - Nimer Sleihat - Amman Arab University \\ Dr- Malek Alharafsheh - Amman Arab University
}

\begin{abstract}
The purpose of this paper is to examine the effect of firm's characteristics (family vs. non- family firms) on disclosure behaviour regarding intellectual capital. The sample is composed of 201 firms from Amman Stock Exchange in 2018. First, this study differentiates three categories of intellectual capital: structural capital, relational capital, and human capital. Second, it examines the influence of the size, the profitability, the leverage, and the industry on the importance of intellectual capital disclosure. The study shows that family firms disclose more intellectual capital information than non- family firms. The results also show that the industry and the size have a significant and positive influence, that profitability and the leverage have a significant and negative influence on capital intellectual disclosure. Furthermore, Jordan family firms seem to disclose more about intellectual capital than Jordan non-family firms do.
\end{abstract}

Keywords:

Voluntary, disclosure, family firms, Jordan family firms, intellectual capital.

Article Received: 18 October 2020, Revised: 3 November 2020, Accepted: 24 December 2020

\section{Introduction}

In the new knowledge economy, wealth is created through the development and management of intellectual capital (IC) (Ricceri and Guthrie, 2009; Hayes and Schaefer,1999; Stewart, 1997). Value creation by the firm is no longer only linked to financial and material resources, but a large part is generated by intangible resources such as research and development, innovation, corporate reputation, brands, employee skills and knowledge, processes, corporate culture, etc. (Ricceri and Guthrie, 2009; Hayes and Schaefer, 1999; Stewart, 1997).

These intangible resources, also known as CIs, are essential to the creation of a company, and are essential to the creation of a new business. of value by the company (Aboody and Lev, 2000; Chaminade and Roberts, 2003; Habersam and Piber, 2003), and on the other hand in the construction of sustainable competitive advantages generating thus increasing market value for the shareholder (Bukh and Johanson, 2003; Holland, 2001). Edvinsson (1997) introduced the definition of IC in his study of the Skandia company.

IC is then defined as the possession of knowledge, applied experience, a technology, customer relationships and key competencies that enable the company to be a leader in the field of competitive on the market. Mouristen et al. (2001) consider this term to include the assets intangible and allows the creation of value for the company. It is partly reflected in the difference between the market value of the company and its book value.

However, Charimande and Roberts (2003) note that it is accepted that the term intangible (or incorporeal) is a technical word used in financial accounting whereas the term $\mathrm{CI}$ is used in the management research field.

Several definitions have thus been proposed to define the notion of IC without reaching a consensus (Beattie and Thomson 2007). Lev and 
Zambon (2003) add that, on the other hand, a broad consensus exists on the categories of intellectual capital, namely human capital, structural capital and relational capital. Similarly, the OECD (2008) considers that the scope of intellectual capital has evolved towards a broader concept that includes human resources and capabilities, structural capital (databases, technology, habits and culture) and relational capital (organizational concepts and processes, networks of customers and suppliers, etc.). Our paper is based on the definition proposed by Edvinsson and Malone (1997), the most frequently used definition in the research work on intellectual capital reporting (Sharabati et al., 2010; Yang and Lin, 2009), a definition that also has the advantage of being convergent with the work cited above.

The literature on family firms, which initially focused on succession problems, has evolved towards other issues such as performance and growth (Carney, 2005; Arrègle and Mari, 2010). Nonetheless, several researchers consider that the specificities of family-owned firms in relation to non-family firms have not been sufficiently studied (Castillo and Wakefield, 2007; Harris et al., 2004; Westhead and Howorth, 2006; Miller et al., 2008).

Salvato and Moores (2010), based on a metaanalysis of research (published between 1982 and 2010) on accounting practices in family firms, identified five articles on voluntary disclosure of information. In this study, no articles dealing with the voluntary disclosure of intellectual capital information by family businesses were identified.

Our article is intended to fill this gap in previous work related to intellectual capital reporting by family businesses. It seeks to demonstrate that there are differences in the disclosure of IC information between family-owned and nonfamily businesses. To this end, we have chosen to analyze the case of companies listed on the Amman Stock Exchange in Jordan for the year 2018.
The article is divided into four sections. The first is devoted to the review of the literature. It includes on the one hand a summary of the work dealing with intellectual capital reporting and on the other hand the particularities of family businesses in terms of voluntary disclosure of information. The second presents the working methodology based firstly on a content analysis of annual reports and secondly on a regression model. The third is devoted to the presentation of the results. The last one presents the discussion of the results obtained.

\section{Literature review}

\subsection{Disclosure of information on intellectual capital}

In a knowledge-based economy, companies identify their core competencies as invisible rather than visible assets. In this context, intellectual capital has become a crucial long-term factor in company performance (Itami, 1989).

The concept of intellectual capital, introduced by the economist John Kenneth Galbraith in 1969, refers to the difference between the market value and the book value of a company. Many researchers see it as a way for a company to create a competitive advantage and improve its performance. One of the first definitions of intellectual capital dates from 1997, according to which intellectual capital is the possession of knowledge, applied experience, technology, customer relations and distinctive skills that provide the company with a competitive advantage in the market (Edvinsson and Malone, 1997). In 2002, Wexler proposed a definition related to the accounting aspect of intellectual capital that allows it to include all intangible assets. Intangible assets include a company's knowledge, information resources, experience, skills, structures, culture and relationships, which together can create wealth.

Guthrie and Petty (2000) have proposed a framework for analysing the components of intellectual capital from the categorisation made by Edvinsson and Malone (1997). This grid 
applied to the analysis of the annual reports of 20 Australian companies made it possible to identify items representing the three categories of intellectual capital (human, internal and external). This study has been replicated by other researchers in other countries: Brennan (2001) in Ireland, April et al (2003) in South Africa, Bozzolan et al (2003) in Italy, Abdolmohammadi (2005) in the United States, Guthrie et al (2006) in Hong Kong and Australia, Campbell and Abdul Rahman (2010) for a single British company over a period from 1978 to 2008 , Li et al $(2008,2012)$ in Great Britain.

Several categories of intellectual capital are thus distinguished. The most commonly used in the literature are related to human capital, relational capital and structural capital (Brooking, 1997). We briefly present these three categories:

- Human capital: is defined as the body of knowledge, experience and skills found in employees. It is an essential factor for the maintenance, value creation and development of the company. Furthermore, according to Ramezan (2011, p. 89), "human capital encompasses the values and attitudes, skills and know-how, the tacit or explicit knowledge that people possess, and their ability to generate it".

- Structural capital: Bontis (2003) considers structural capital to be the knowledge rooted in the organisation. These are the factors that are intimately linked to the organisation's structure and processes.

- The relational capital: it allows to group together everything that links the company to its environment. This includes external relations with customers, suppliers, investors, creditors, etc.

Rylander et al (2000) state that the purpose of intellectual capital disclosure is to provide appropriate, reliable and timely information to those who need it to make decisions about their relationship with the company.

Research on voluntary disclosure of intellectual capital-related information can be divided into two categories. The first category is descriptive in nature, while the second is explanatory in nature. This classification goes beyond the methodological aspect to include the nature of the results found. Indeed, studies of a descriptive nature aim either to examine the categories and sub-categories of intellectual capital most disclosed by companies, or to analyse the evolution over time of this reporting (Campbell and Abdul Rahman, 2010). Explanatory work, on the other hand, seeks to identify the factors influencing voluntary disclosure of intellectual capital information. Some of this work is briefly presented below.

\subsubsection{Descriptive studies on intellectual capital}

Descriptive studies have used manual content analysis or assisted by specialised analysis programmes (Bontis, 2003). Annual reports were the most widely used media (Beattie et al., 2002; Campbell, 2000). Other sources of information were also used (company websites, presentations during general meetings, press briefings, analysts' reports, etc.). This work was often carried out over a short period of time (less than 3 years). Because of the manual coding of data and the difficulty of coding a large number of media, few studies, apart from the study by Campbell and Abdul Rahman (2010), have followed longitudinal approaches to our knowledge. Other work has focused on the study of intellectual capital disclosure in a particular country (Britain, Ireland, Australia, Italy, Portugal, Mexico, New Zealand, Hong Kong, etc.). Some authors have taken a comparative approach across several countries (Bozzolan et al., 2006; Cerbioni and Parbenotti, 2007).

The results of these studies have shown that the level of disclosure of information on intellectual capital is low. Structural capital is the component most covered in reporting, while human capital remains a topic little discussed in annual reports (Whiting and Miller, 2008). 
It should be noted that there are two types of information disclosed on intellectual capital by companies. The first is information of a narrative and qualitative nature. The second is quantitative information (monetary or non-monetary). All the work focused on intellectual capital reporting suffers from several limitations. The main one is linked to the validity of the coding methods used in this research, which are not very stable and are based on sometimes subjective approaches. This does not make it easy to compare the different works in order to draw definitive conclusions.

\subsubsection{Explanatory studies on the disclosure of information on intellectual capital}

Several research studies have examined the factors that motivate companies to publish intellectual capital information (Bozzolan et al., 2006; Li et al., 2008; Whithing and Woodcock, 2011; Li et al., 2012).

The main theories mobilized are agency theory $(\mathrm{Li}$ et al., 2008; White et al., 2007; Oliveira et al., 2006), asymmetric information theory (Brugggen et al., 2009; Bozzolan et al., 2006,), signal theory (Oliveira et al., 2006) and legitimacy theory. Debicki et al (2009) (cited by Arrègle and Mari, 2010) assert, through a review of 291 Englishlanguage articles published on family businesses in 30 management journals between 2001 and 2007 , the predominance of agency theory and the resource-based approach. They identified a number of major themes covered, of which governance of family businesses (19.2\%), leadership and ownership (15.8\%) and succession $(15.1 \%)$ are the most prevalent.

Several reasons for companies to disclose more information about intellectual capital have been identified in the literature. Among these reasons, we can cite the following:

- reduce information asymmetry;
- allow the reduction of the cost of capital of the company (Williams, 2001);

- improve the liquidity of the stock market;

- increase the demand for corporate securities (Diamond and Verrecchia, 1991);

- have positive (external) effects on corporate reputation and trust in the management of the company.

Based on the above theories, the influence of several factors was tested (size, industry, debt, financial performance, dual listing, age of the company, type of auditor, governance mechanisms). The results showed that the most important determinants of intellectual capital disclosure are size and industry (Whithing and Woodcock, 2011). But more and more research emphasise the role played by governance mechanisms. Indeed, they assume that oversight bodies, including the board of directors, are the main actors in financial communication (Holland, 2006; Abeysekera, 2010; Hidalgo et al., 2011). The agency theory provides a basis for this kind of research.

As such, $\mathrm{Li}$ et al (2008) have incorporated governance factors (composition of the board of directors and audit committee, duality, capital structure) to explain the intellectual capital reporting of UK companies. They confirmed the major role played by the composition of the board of directors. Hidalgo et al (2011) included in their study a variable relating to the presence of a family in the capital structure. The effect of this variable on the disclosure of intellectual capital by about 100 Mexican companies from 2004 to 2007 was not demonstrated. However, the results showed that the size of the board has a significant impact on intellectual capital disclosure.

Table 1 presents a summary of the work analysed in this paper relating to the disclosure of information on the IC. They are listed in descending chronological order.

Table 1. Examples of work on Intellectual Capital Disclosure

\begin{tabular}{|l|l|l|l}
\hline Authors/Year & Sample & Variables & Overall results \\
\hline
\end{tabular}




\begin{tabular}{|c|c|c|c|}
\hline Li et al. (2012) & $\begin{array}{l}100 \text { British companies, } \\
\text { technology sectors year } \\
2005\end{array}$ & $\begin{array}{l}\text { Size audit committee, } \\
\text { frequency of meetings, } \\
\text { independence, financial } \\
\text { expertise of members }\end{array}$ & $\begin{array}{l}\text { Disclosure on the IC is positively } \\
\text { associated with the characteristics of the } \\
\text { audit committee (size, frequency of } \\
\text { meetings), no significant relationship with } \\
\text { the independence and expertise of the } \\
\text { members. }\end{array}$ \\
\hline $\begin{array}{l}\text { Hidalgo et al. } \\
(2011)\end{array}$ & $\begin{array}{l}100 \text { companies listed in } \\
\text { Mexico for the period } \\
2005-2007\end{array}$ & $\begin{array}{l}\text { Board of Directors, } \\
\text { capital structure, size, } \\
\text { indebtedness, } \\
\text { performance }\end{array}$ & $\begin{array}{l}\text { A significant proportion of the capital } \\
\text { held by institutional investors has a } \\
\text { negative effect on the voluntary disclosure } \\
\text { of IC. }\end{array}$ \\
\hline $\begin{array}{l}\text { Whiting \& } \\
\text { Woodcock } \\
(2011)\end{array}$ & $\begin{array}{l}70 \text { Australian listed } \\
\text { companies, year } 2006\end{array}$ & $\begin{array}{l}\text { Industry, capital structure, } \\
\text { indebtedness, type of } \\
\text { auditors, age }\end{array}$ & $\begin{array}{l}\text { - The relational capital is the most present. } \\
\text { - Companies in sectors based on } \\
\text { on knowledge or technology and those } \\
\text { audited by a Big } 4 \text { disclose more } \\
\text { information about the IC than others. } \\
\text { - Concentration of capital, indebtedness } \\
\text { and age have no influence on the } \\
\text { disclosure of IC. }\end{array}$ \\
\hline $\begin{array}{l}\text { Campbell \& } \\
\text { Abdul Rahman } \\
\text { (2010) }\end{array}$ & $\begin{array}{l}\text { The annual reports of } \\
\text { only one company } \\
\text { (Marks \& Spencer) were } \\
\text { analysed over a long } \\
\text { period from } 1978 \text { to } \\
2008 .\end{array}$ & & $\begin{array}{l}\text { An overall increase in IC disclosure } \\
\text { during the period under review. There is a } \\
\text { significant growth in relational capital and } \\
\text { a change in the order of subcategories } \\
\text { over the period. }\end{array}$ \\
\hline Li et al. (2008) & $\begin{array}{l}100 \text { British companies } \\
\text { from the technology } \\
\text { sectors. Year } 2005\end{array}$ & $\begin{array}{l}\text { Attributes of corporate } \\
\text { governance, age, } \\
\text { performance and } \\
\text { company size }\end{array}$ & $\begin{array}{l}\text { A meaningful relationship between IC } \\
\text { disclosure and all attributes of corporate } \\
\text { governance other than the duality of the } \\
\text { executive. }\end{array}$ \\
\hline $\begin{array}{l}\text { Cerbioni \& } \\
\text { Parbonetti } \\
(2007)\end{array}$ & $\begin{array}{l}\text { 54 European companies } \\
\text { in the biotechnology } \\
\text { sector. Period: } 2001- \\
2004 \text {. }\end{array}$ & $\begin{array}{l}\text { Governance mechanisms, } \\
\text { Indebtedness, country, } \\
\text { capital structure, country } \\
\text { legislation }\end{array}$ & $\begin{array}{l}\text { Governance variables influence IC } \\
\text { disclosure. } \\
\text { The presence of independent directors is } \\
\text { positively associated with structural } \\
\text { capital disclosure. The duality of the } \\
\text { director is negatively associated with the } \\
\text { disclosure of voluntary forward-looking } \\
\text { information. }\end{array}$ \\
\hline $\begin{array}{l}\text { Bozzolan et al. } \\
(2006)\end{array}$ & $\begin{array}{l}30 \text { companies from } \\
\text { Great Britain and } 30 \\
\text { from Italy. Year } 2001\end{array}$ & $\begin{array}{l}\text { Country, industry, size, } \\
\text { debt, capital structure, } \\
\text { performance. }\end{array}$ & $\begin{array}{l}\text { Size and sector of activity are } \\
\text { determinants of IC disclosure. } \\
\text { Nationality and origin of the company do } \\
\text { not influence disclosure of the IC. }\end{array}$ \\
\hline $\begin{array}{l}\text { Oliveira et al. } \\
\text { (2006) }\end{array}$ & $\begin{array}{l}56 \text { listed companies in } \\
\text { Portugal, year } 2003 \text {. }\end{array}$ & $\begin{array}{l}\text { Size, industry, capital } \\
\text { structure, type of auditor, } \\
\text { performance. }\end{array}$ & $\begin{array}{l}\text { Size, industry, type of auditor and capital } \\
\text { structure determine the level of IC } \\
\text { disclosure. }\end{array}$ \\
\hline $\begin{array}{l}\text { Bozzolan et al. } \\
(2003)\end{array}$ & $\begin{array}{l}30 \text { Italian listed } \\
\text { companies ( } 15 \text { from the } \\
\text { high-tech sector and } 15 \\
\text { from the traditional } \\
\text { sectors), year } 2001 .\end{array}$ & $\begin{array}{l}\text { Sector of activity } \\
\text { Size }\end{array}$ & $\begin{array}{l}\text { Important disclosure on relational capital. } \\
\text { Size and sector are not determinative of } \\
\text { the content of IC disclosure. } \\
\text { These two factors are determinative in } \\
\text { explaining the volume of IC disclosure. }\end{array}$ \\
\hline
\end{tabular}




\subsection{Voluntary disclosure of information by family businesses}

The vast majority of research on IC disclosure has been conducted on the basis of listed and often large companies. Researchers believe that no studies have focused on analysing the disclosure of intellectual capital information by family businesses. The case of family businesses in Jordan could be interesting and would allow researchers to understand the practices of voluntary disclosure of information on intellectual capital and their determinants.

Before dealing with this issue, it is necessary to briefly define the notion of family business. Family businesses play a central role in the economic development of several countries. On average, they generate $70-90 \%$ of GDP each year. They constitute more than $80 \%$ of companies in Europe (FFI, 2010). However, there is no consensus on the definition of a family business. The literature proposes a set of definitions based on several criteria such as the percentage of family ownership, strategic control and day-to-day management by family members, etc. The definition of a family business is based on a number of criteria. (Astrachan and Kolenko, 1994; Astrachan and Shanker, 2003). Ali et al (2007), in their empirical study of S\&P 500 companies, consider as a family business any entity whose founder and/or his descendants become managers, board members or majority shareholders. This definition is used to distinguish between family and non-family firms in our sample. This will allow the researcher to compare reporting practices between family and non-family businesses.

The theoretical framework is based on agency theory. Indeed, research, having applied agency theory to family businesses, has identified agency and rootedness as the two main characteristics that differentiate family from non-family businesses (Chrisman et al., 2003). Altruism and opportunism within a family business can manifest itself through the mobilisation and use of human capital. Indeed, in some cases, family businesses tend to recruit managers from within the family who do not have the required technical and managerial skills. This is not the case for non-family businesses.

Chua et al (2003) consider that one of the most important questions that need to be addressed in a theory of the family firm is how and why this form of organization behaves and acts in a way that is distinctive of a non-family firm. These differences could arise from a disparity in vision or goals. They may also be the result of values, resources, capabilities, strategies, style, etc.

Salvato and Moores (2010) find that accounting practices in family businesses have been the subject of very little research. As such, they show the value of conducting empirical research on the interface between family businesses and accounting practices.

In the previous literature, research analysing the accounting practices of family businesses has focused on the quality of results, the quality of earnings forecasts, governance mechanisms (Ali et al., 2007), earnings forecasts, earnings warnings and the frequency of press briefings (Chen et al., 2008). The main theme of this work is results management and the specificities of family companies with regard to these practices.

According to Salvato and Moores (2010), this could be explained by the fact that the literature on voluntary disclosure of information tends to consider shareholders as a homogeneous group. The latter all prefer companies to disclose more voluntary information in order to reduce the asymmetry of information between shareholders and managers. This hypothesis ignores the fact that some shareholders, especially families, who hold a large share of the company's capital, may have a different strategy in terms of extrafinancial communication.

In this context, Ho and Wong (2001) find a negative relationship between the proportion of family members on the board of directors and the voluntary disclosure of family businesses listed in Hong Kong. Lakhal (2005) also demonstrates the presence of a negative relationship between the 
proportion of family members on the board of directors of family-owned companies in Jordan and the voluntary disclosure of results.

On the other hand, Ali et al (2007) argue in their study that S\&P 500 family firms seem to communicate quarterly earnings forecasts to a greater extent than non-family firms.

Chen et al (2008) find that family-controlled S\&P 1500 companies prefer to disclose less information on a voluntary basis since they provide few earnings forecasts and press conferences. However, they communicate more earnings alerts to avoid disputes with shareholders and thus penalize their reputations if they do not disseminate bad news in time.

This work shows that the results on voluntary disclosure of information by family businesses are contradictory. This can be explained by the diversity of voluntary disclosure practices and the multitude of such objects. The motivations for disclosing voluntary information may be different depending on its nature.

Table 2 presents a summary of the work analysed in the literature on the disclosure of voluntary information by family businesses. These works are classified in descending chronological order.

Table 2. Examples of work on voluntary disclosure of information by family businesses

\begin{tabular}{|c|c|c|c|}
\hline Authors/Year & Sample & Variables & Overall results \\
\hline $\begin{array}{lll}\text { Chau et } & \text { Gray } \\
(2010) & & \end{array}$ & $\begin{array}{l}273 \text { companies listed on } \\
\text { the Hong Kong market } \\
\text { during the year } 2002\end{array}$ & $\begin{array}{l}\text { This research is a continuation of } \\
\text { the work carried out on the } \\
\text { disclosure of information on IC. } \\
\text { Understanding the link between } \\
\text { the level of disclosure and its } \\
\text { determinants }\end{array}$ & $\begin{array}{l}\text { - For a moderate level of family } \\
\text { ownership (25\% or less), the } \\
\text { extent of voluntary disclosure is } \\
\text { low. } \\
\text { - The presence of an independent } \\
\text { CEO is positively associated with } \\
\text { the level of voluntary disclosure. }\end{array}$ \\
\hline Chen et al. (2008) & $\begin{array}{l}\text { S\&P } 1500 \text { companies } \\
\text { during the period 1996- } \\
2000\end{array}$ & $\begin{array}{l}\text { Earnings forecasts, press } \\
\text { briefings, size of the Board of } \\
\text { Directors (BoD), independence of } \\
\text { the BoD, number of financial } \\
\text { analysts }\end{array}$ & $\begin{array}{l}\text { Compared to non-family } \\
\text { businesses, family businesses } \\
\text { provide fewer earnings forecasts } \\
\text { and fewer press briefings, but } \\
\text { more earnings warnings. } \\
\text { Preferences for less voluntary } \\
\text { disclosure from family-owned } \\
\text { businesses whose owners are } \\
\text { invested in management and opt } \\
\text { for long-term investments are } \\
\text { balanced by considerations of } \\
\text { reducing the cost of capital. }\end{array}$ \\
\hline Ali et al. (2007) & $\begin{array}{l}\text { S\&P } 500 \text { companies } \\
\text { over the period 1998- } \\
2002\end{array}$ & $\begin{array}{l}\text { Earnings management, earnings } \\
\text { forecasts, disclosure of } \\
\text { governance practices, number of } \\
\text { financial analysts }\end{array}$ & $\begin{array}{l}\text { Family-owned businesses report } \\
\text { better results, are more likely to } \\
\text { warn about poor results, but } \\
\text { communicate less about } \\
\text { governance practices. }\end{array}$ \\
\hline Ho \& Wong (2001) & $\begin{array}{l}\text { Two questionnaires: one } \\
\text { sent to CFOs of }\end{array}$ & $\begin{array}{l}\text { Audit Committee, independence } \\
\text { of the Board of Directors, }\end{array}$ & $\begin{array}{l}\text { The presence of an audit } \\
\text { committee is positively associated }\end{array}$ \\
\hline
\end{tabular}




\begin{tabular}{|l|l|l|} 
companies listed in & presence of family members on & with voluntary disclosure. \\
Hong Kong, the other to & the Board of Directors & The proportion of family \\
financial analysts of the & & members on the board is \\
same stock exchange & & negatively associated with \\
(late 1997 and early & voluntary disclosure. \\
$1998)$ &
\end{tabular}

Previous studies have confirmed the role played by certain characteristics of firms in the voluntary disclosure of information. According to $\mathrm{Li}$ et al (2008), large firms are more visible and tend to publish more voluntary information in order to cope with pressure from the various stakeholders. According to Cerbioni and Parbonetti (2007), successful companies tend to disclose more information because they want to show their good performance. The same result has been confirmed by Gul and Leung (2004) and Garcia-Meca et al (2005) regarding the level of disclosure of information on IC.

Agency theory has been used to explain the relationship between the extent of disclosure and the level of indebtedness of the firm (Abdulrahman and Abdul Hamid, 2012). According to Jensen and Meckling (1976), creditors demand more information about the firm if it is highly indebted. They want to know whether the entity is able to meet its liabilities. This is a way of assessing the risks of wealth transfer to shareholders. The demand for information on IC is therefore probably an increasing function of indebtedness (Escaffre, 2002). In this context, White et al (2007) found that the level of debt had a significant impact on the level of voluntary disclosure of IC among biotechnology companies in Australia.

Several other previous studies have identified that companies belonging to knowledge-based industries disseminate more information about IC (Bozzolan et al., 2003, 2006; Garcia-Meca et al., 2005; Cerbioni and Parbonetti, 2007; Li et al., 2008). This category covers the fields of the Internet, biotechnology, entertainment and leisure, high technology, media, software design, integration systems, telecom, web services, etc.
(Bozzolan et al., 2003, 2006; Garcia-Meca et al., 2005; Cerbioni and Parbonetti, 2007; Li et al., 2008). Other non-knowledge-based sectors include catering, automotive, chemicals, construction, electronics, industry, energy, oil, services, textiles, tourism, etc.

This non-exhaustive review of the work dealing on the one hand with IC reporting and on the other hand with the practices of family businesses in terms of voluntary disclosure of information, shows the need to conduct empirical research in order to examine the specificities of IC reporting by family businesses.

Family businesses have certain particularities compared to non-family businesses. Shareholders generally take a long-term investment perspective and ensure the transmission of wealth from one generation to the next. Thus, the strategy of voluntary disclosure of intellectual capital information may be subject to counter-arguments. On the one hand, leaders who are often family members prefer to disclose less voluntary information (Chen et al., 2008). On the other hand, shareholders who are family members have easier access to information and have fewer problems of information asymmetry. On the other hand, a good voluntary disclosure policy can reduce the cost of capital, better inform the market and attract new investors. This would allow the company to develop better and not rely heavily on debt to finance its investments.

In this context, the application of agency theory to family businesses has a certain peculiarity. Indeed, Ali et al (2007) distinguish between level 1 and level 2 agency problems. Compared to non-family businesses, family firm face fewer agency problems due to the separation between owner/shareholders and managers (type 1 agency 
problems). However, they are subject to more agency problems between shareholders with the power to control the company and others (type 2 agency problems). These characteristics specific to family businesses seem to influence voluntary disclosure practices on intellectual capital.

The researchers assume that there are significant differences between family and non-family companies listed on the Amman Stock Exchange with regard to the understanding of disclosure of intellectual capital information. The research hypothesis is that the level of disclosure of intellectual capital information in annual reports differs between family and non-family companies.

\section{Research methodology}

In this section, begins with an explain on how the sample was put together. Secondly, describe the method used to determine the intellectual capital disclosure score. Finally, present the regression model used.

\subsection{Description of the sample and data collection}

The initial sample consisted of companies listed on the Amman Stock Exchange. The final sample is made up of 201 companies, after elimination: companies in the banking and insurance sectors, those whose 2018 reference documents were not available online and those whose financial data were missing.

Family businesses were identified on the basis of the criteria of Astrachan and Kolenko (1994) and used by Ali et al. (2007), i.e., any business in which the same family owns more than $50 \%$ of the capital in the case of unlisted companies and $10 \%$ in the case of listed companies, or those in which one or more family members manage the company or have transferred management to other generations of the family.

The classification of the companies in our sample involved several steps:
- Firstly, the capital breakdown of each company in the sample from the reference document was retreived.

- Then, the main shareholders were identified and added up their shares in the company's capital if they belonged to the same family. In some cases, it was necessary for more precise research on the company's main shareholders. The ASE database was used to identify the owners of financial holding companies who own shares in family businesses. An Internet search was conducted to identify family relationships between certain shareholders. The three co-authors cross-referenced and verified the data collected.

- Finally, considering a company to be family owned (coded 1) when the cumulative share of family shareholders exceeds $10 \%$ of the company's share capital and some family members sit on the board of directors. Otherwise, the company is considered non-family (coded $0)$.

This phase enabled us to identify 71 family firms and 130 non-family firms.

As for the sectors of activity, Bozzolan et al (2006) and $\mathrm{Li}$ et al (2008) was considered the sectors related to the internet, biotechnology, entertainment and leisure, high technology, media, software design, integration systems, telecoms and web services, as highly knowledge-based sectors. They are coded with a value equal to 1 . The other sectors are coded 0 and cover catering, automotive, chemicals, construction, industry, energy, oil, services, textiles, tourism, etc.

The data collection and coding period for the reference documents lasted from January to July 2019. The other financial data (size, performance and indebtedness) were collected from June 2019. Table 3 summarises the composition of our sample

Table 3: Sample composition

\begin{tabular}{|c|c|c|c|}
\hline & Family businesses & Non family businesses & Total \\
\hline
\end{tabular}




\begin{tabular}{|c|c|c|c|}
\hline $\mathrm{N}$ & 71 & 130 & 201 \\
\hline$\%$ & $35,32 \%$ & $64,67 \%$ & $100 \%$ \\
\hline & Firms in highly knowledge-based sectors & Businesses in other sectors & Total \\
\hline $\mathrm{N}$ & 61 & 140 & 201 \\
\hline$\%$ & $30,34 \%$ & $69,65 \%$ & $100 \%$ \\
\hline
\end{tabular}

\subsection{Calculating the intellectual capital disclosure score}

The calculation of the IC disclosure score is based on the content analysis of the reference document. This approach is one of the most common research methods used in examining voluntary disclosure of IC information (Guthrie and Petty, 2000; April et al., 2003; Guthrie et al., 2004; Li et al., 2008; Campbell and Abdul Rahman, 2010).

The analysis was carried out on the basis of the 2018 reference documents of family and nonfamily businesses listed on the Amman Stock Exchange. The fiscal year-end for our sample runs from the end of March 2018 to the end of February 2019. Several companies in our sample do not close their accounts at 31 December each year.

Once the annual reports have been collected from the companies' websites or from the Jordan Securities Commission) website, an electronic version is used.

Referring to the grid proposed by Campbell and Abdul Rahman (2010), Researchers distinguished between the different categories of IC: human, structural and relational. This approach is consistent with the method used by other authors (Beattie and Thomson, 2007; Li et al., 2008; Striukova et al., 2008; Li et al., 2012). Thus, the coding of reference documents is done manually. The hypothesis concerns the examination of the existence of a difference in the disclosure of information on IC between family and non-family businesses. This hypothesis was tested on the basis of the volume of information disclosed on IC in the reference documents of the companies in our sample. As such, researchers used the word as the unit of analysis and the number of words as an indicator of the volume of information on IC. For each reference document, researchers identified the words related to the IC. The words concerned are taken from the analysis grid. By adding the total number of words per IC category, we have the total number of words linked to the IC. The latter is divided by the total number of words contained in the reference document.

The score (ICDSCORE) is calculated as follows:

\section{Human Capital Score + Structural Capital Score + Relational Capital Score}

\section{Total number of words in the reference document}

Note that the different scores are calculated as follows:

Human capital score $=$ Sum of the words published on each of the human capital items.

Structural capital score $=$ Sum of words published on each of the structural capital items.

Relational capital score $=$ Sum of words published on each of the items of the relational capital.

\subsection{Regression model and definition of variables}

In order to test the level of association between the dependent variable (ICDSCORE) and the family character of the firm, a multiple linear regression model was used. Other variables (size, performance, indebtedness and sector of activity) were introduced into the model.

Thus, the regression model is as follows:

$\mathrm{ICDSCORE}=\alpha+\beta 1 F A M+\beta 2 \mathrm{SIZE}+$ $\beta 3$ PERF $+\beta 4$ RDEBT $+\beta 5$ SECT $+\varepsilon$ 
With:

ICDSCORE: total disclosure score on the IC,

FAM: binary variable $=1$ if the company is a family business and 0 otherwise,

SIZE: total asset $\log$,

PERF: performance measured by Return on Investment (ROI),

RDEBT: Debt ratio,

SKBS: binary variable $=1$ if the company belongs to a strongly knowledge-based sector and 0 otherwise.

The financial variables (total assets, return on investment and financial debt) are calculated at the end of the fiscal year from the Thomson Reuters DataStream database.
4. Results

In this section, the results obtained are presented. These are firstly descriptive statistics and correlations and secondly the results of the model explaining the extent of IC disclosure.

\subsection{Descriptive statistics and correlation analysis}

Descriptive statistics for the variables in the total sample are presented in Table 4 (Panel A). For the subsets (family businesses and non-family businesses), the descriptive statistics of the variables are presented in panels $\mathrm{B}$ and $\mathrm{C}$ respectively in the same table.

Table 4. Descriptive statistics

\begin{tabular}{|c|c|c|c|c|}
\hline Variables & Minimum & Maximum & Mean & Standard deviation \\
\hline Panel A: global sample $(n=201)$ & & & & \\
\hline ICDSCORE & 0,0241928 & 0,05461956 & 0,0372638 & 0,0056254 \\
\hline HUCSCORE & 0,0069449 & 0,02138462 & 0,0131361 & 0,0022848 \\
\hline STRUSCORE & 0,0052915 & 0,02597514 & 0,0108549 & 0,0032479 \\
\hline RECSCORE & 0,0068724 & 0,02588036 & 0,0132727 & 0,0032140 \\
\hline SIZE & 2,189416 & 12,354328 & 7,105614 & 2,253800 \\
\hline PERF & $-0,6268$ & 0,8475 & 0,0274 & 0,1069 \\
\hline RDEBT & 0,0000 & 2,3353 & 0,2489 & 0,2164 \\
\hline SECT & 0,00 & 1,00 & 0,30 & 0,46 \\
\hline Panel B: Family businesses $(n=71)$ & & & & \\
\hline ICDSCORE & 0,0241928 & 0,0504396 & 0,0385599 & 0,0053641 \\
\hline HUCSCORE & 0,0080219 & 0,0195597 & 0,0135546 & 0,0023105 \\
\hline STRUSCORE & 0,0058650 & 0,0185911 & 0,0109228 & 0,0031835 \\
\hline RECSCORE & 0,0077351 & 0,0231745 & 0,0140824 & 0,0030047 \\
\hline SIZE & 3,146606 & 11,197310 & 7,365097 & 2,055144 \\
\hline PERF & $-0,2836$ & 0,1927 & 0,0353 & 0,0620 \\
\hline RDEBT & 0,0000 & 0,7301 & 0,2558 & 0,1674 \\
\hline SECT & 0,00 & 1,00 & 0,28 & 0,453 \\
\hline $\begin{array}{l}\text { Panel C: Non family businesses }(n= \\
130)\end{array}$ & 0.0245837 & 0.0546195 & 0.0365559 & 0.0056585 \\
\hline ICDSCORE & 0,0069449 & 0,0213846 & 0,0129075 & 0,0022468 \\
\hline HUCSCORE & 0,0052915 & 0,0259751 & 0,0108178 & 0,0032942 \\
\hline STRUSCORE & 0,0068724 & 0,0258803 & 0,0128305 & 0,0032494 \\
\hline RECSCORE & 2,189416 & 12,354329 & 6,9638965 & 2,3507860 \\
\hline SIZE & $-0,6268$ & 0,8475 & 0,0231 & 0,1249 \\
\hline
\end{tabular}




\begin{tabular}{|l|l|l|l|l|}
\hline PERF & 0,0000 & 2,3353 & 0,2452 & 0,2394 \\
RDEBT & 0,00 & 1,00 & 0,32 & 0,46 \\
SECT & & & & \\
& & & & \\
& & & & \\
\hline
\end{tabular}

The variables are defined as follows:

ICDSCORE: disclosure score on the IC,

HUCSCORE: human capital disclosure score,

STRUSCORE: disclosure score on structural capital,

RECSCORE: disclosure score on relational capital,

SIZE: logarithm of the total asset,

PERF: performance measured by ROI,

RDEBT: debt ratio

SKBS: 1 if the company belongs to the knowledge-intensive sector and 0 if not.

The results show the extent of disclosure of information in the three IC categories. Familyowned businesses globally disclose more information about IC than non-family businesses. Table 4 also shows that the extent of disclosure differs between family and non-family businesses. The average disclosure scores for Relational Capital and Human Capital are higher for familyowned businesses. On the other hand, non-family businesses compared to family businesses disclose relatively more information on structural capital.

This study shows that attributes of relational capital were more widely disclosed than those of structural and human capital. This finding is consistent with those of Bozzolan et al (2003) in Italy, Gurthie and Petty (2000) in Australia and Goh and Lim (2004) in Malaysia. This result remains valid for both family and non-family firms.
The results of the descriptive statistics for the independent variables suggest that several large firms indexed in the Amman Stock Exchange are family owned. The average size of family firms is larger than that of non-family firms. Consistent with previous literature, family firms perform better than non-family firms (Chen et al., 2008; Anderson and Reeb, 2003). However, contrary to the work of Chen et al. (2008), family businesses indexed to the Amman Stock Exchange seem to use debt more than non-family businesses.

Appendix 2 presents the result of the correlation analysis between the independent variables of the model. No significant correlations were observed between these variables.

In order to better demonstrate the existence of a difference in disclosure of IC information between family and non-family businesses, the mean difference test was performed. Table 5 presents the results.

Table 5. Test of difference in averages between family and non-family businesses

\begin{tabular}{|l|l|l|l|l|}
\hline Variables & Family businesses & $\begin{array}{l}\text { Non-Family } \\
\text { businesses }\end{array}$ & Gap & T-Student \\
\hline ICDSCORE & 0,0385599 & 0,0365559 & 0,0020039 & $2,444^{* *}$ \\
HUCSCORE & 0,0135546 & 0,0129075 & 0,0006471 & $1,932^{*}$ \\
\hline
\end{tabular}




\begin{tabular}{|l|l|l|l|l|}
\hline STRUSCORE & 0,0109228 & 0,0108178 & 0,0001049 & 0,218 \\
RECSCORE & 0,0140824 & 0,0128305 & 0,00125192 & $2,680^{* *}$ \\
\hline
\end{tabular}

$*, * *$ denote significance levels at $10 \%$ and $5 \%$ respectively.

Table 5 shows that there is a difference between the level of disclosure on IC at the global level and at the level of the relational capital category with a level of $5 \%$. Disclosure on human capital appears to be different between family and nonfamily businesses at $10 \%$. On the other hand, no significant difference is found for structural capital between the two types of companies.

\subsection{The results of the regression model}

Table 6 summarizes the results of the regression of the level of IC disclosure and the independent variables. The latter reports an acceptable adjusted $\mathrm{R}^{2}$ of $16.4 \%$.

Table 6. Results of the regression model (ICDSCORE)

\begin{tabular}{|l|c|c|c|c|c|}
\hline \multirow{2}{*}{ Model } & \multicolumn{2}{|l|}{$\begin{array}{l}\text { Non-standardized } \\
\text { coefficients }\end{array}$} & $\begin{array}{l}\text { Standardized } \\
\text { coefficients }\end{array}$ & Sig. \\
\cline { 2 - 6 } & B & $\begin{array}{c}\text { Standard } \\
\text { Error }\end{array}$ & Beta & \\
\hline (Constant) & 0.0342 & 0.0014 & & 24.2834 & 0.0000 \\
\hline FAM & 0.0021 & 0.0007 & 0.1832 & 2.8216 & $0.0052^{* *}$ \\
\hline SIZE & 0.0003 & 0.0001 & 0.1202 & 1.7267 & 0.0857 \\
\hline PERF & $\begin{array}{c}-6.5495 E- \\
05\end{array}$ & $3.4819 \mathrm{E}-05$ & -0.1245 & -18810 & $0.0614^{*}$ \\
\hline RDEBT & $\begin{array}{c}-4.2133 \mathrm{E}- \\
05\end{array}$ & $1.7054 \mathrm{E}-05$ & -0.1623 & -24705 & $0.0143^{* *}$ \\
\hline SECT & 0.0043 & 0.0008 & 0.3600 & 5.2249 & $0.0000^{* * *}$ \\
\hline
\end{tabular}

$*$ significant at the $10 \%$ level, $* *$ significant at the $5 \%$ level, $* * *$ significant at the $1 \%$ level $\mathrm{R}^{2}=0.184$, adjusted $\mathrm{R}^{2}=0.164, \mathrm{~F}$-value $=8.873, \mathrm{p}$-value $=0.000$

ICDSCORE: total disclosure score on the IC,

FAM: Binary variable $=1$ if the company is a family business and 0 otherwise,

SIZE: total asset log,

PERF: performance measured by ROI,

RDEBT: Debt ratio,

SKBS: Binary variable $=1$ if the company belongs to a strongly knowledge-based sector and 0 otherwise

The basic assumption is that family businesses have different IC disclosure practices than nonfamily businesses. Descriptive statistics have led to the conclusion that the overall score of familyowned businesses is higher. Difference-of-means tests showed that there is a difference in disclosure at the overall IC level as well as for relational and human capital. On the other hand, no difference was observed for structural capital. The multivariate regression model showed that the family character of the companies in our sample has an influence on the level of disclosure of information on IC. Our main hypothesis is confirmed.

\section{Discussion of the results}

Table 6 shows that the FAM variable is significant at the 5\% level. Concluding, in line with our expectations, that there are differences between the level of disclosure of information at the 
aggregate level (ICDSCORE) on the IC of family and non-family businesses. Indeed, the presence of family characteristics leads to an increase in the volume of information published in the IC reference documents. Thus, at the global level, family businesses disclose more information on IC than non-family businesses. These results confirm the findings of Salavato and Moores (2010). The latter consider that family shareholders, having the power of control in the company, play a decisive role in accounting practices.

The size and industry variables are significant at the $10 \%$ and $1 \%$ level respectively. The positive meaning found corresponds to the expected meaning. This result is consistent with previous studies. Indeed, companies belonging to highly knowledge-based sectors such as high technology value their IC more and report more information about it (Bozzolan et al., 2006 Woodcock, 2011). Whiting and Woodcock (2011) argue that this result is due to the fact that these firms have few physical resources. As a result, they tend to compensate for the lack of resources in the financial statements by disclosing detailed information about the IC. This communication would allow the company to find a kind of legitimacy in its sector.

Researchers have also shown that larger firms tend to disclose more information about IC, consistent with the results found by Bozzolan et al (2003) and Hackston and Milne (1996). In contrast, Garcia-Meca et al (2005) found no significant link between IC disclosure and firm size. Based on the empirical results of our research, financial performance as measured by ROI is significantly associated with the extent of disclosure of IC in the registration documents of Amman Stock Exchange companies. The negative direction found means that the best performing companies do not pay attention to this type of publication. This result is not consistent with previous studies that failed to find a link between the extent of IC disclosure and performance
(Williams, 2001; Beaulieu et al., 2002; Oliveira et al., 2006; Yau et al., 2009).

As for the level of indebtedness, the results of this study show that the company's level of indebtedness is significantly and negatively correlated with the overall level of IC disclosure. This means that indebted companies disclose less information on IC. Concluding that companies listed on the Amman Stock Exchange seek to resolve agency problems through other means. Previous studies have had mixed results in this respect. Indeed, for the same Australian context, Whiting and Woodcock (2011) failed to find a significant link, while White et al (2007) found a positive and significant link between indebtedness and the level of disclosure on the IC. The result seem to be consistent with the results already obtained by Meek et al (1995) on the relationship between indebtedness and voluntary disclosure in general.

\section{Conclusion}

The objective of this research is to study the determinants of the level of voluntary disclosure of IC information in the reference documents of family and non-family companies listed on the Amman Stock Exchange in Jordan. Data was collected from the reference documents of 201 companies from different sectors.

Firstly,a content analysis was conducted, which enabled researchers to calculate the disclosure score for the different categories of IC for the year 2018. The results showed that family businesses (compared to non-family businesses) disclose more on relational capital and human capital, but less on structural capital.

Second, the regression results showed that family businesses appear to report more on IC in annual reports than non-family businesses. In addition, industry and size play a rather important role in communication in the reference documents of family and non-family companies. Indeed, larger companies and companies belonging to sectors based on the intensive use of technology and knowledge pay more attention to IC. Performance 
and indebtedness have a negative impact on the extent of disclosure on IC.

This research is a continuation of the work carried out on the disclosure of information on IC. Understanding the link between the level of disclosure and its determinants should make it possible to improve knowledge of companies' behaviour in terms of voluntary disclosure of nonfinancial information.

As with any research work, this article suffers from a number of limitations. The first concerns the size of the sample, which was limited to family businesses listed on the Amman Stock Exchange. However, the sample is comparable to the majority of work dealing with IC disclosure and using content analysis of annual reports as a basis for coding. The second limitation concerns the use of reference documents as the sole medium for IC disclosure. Other media are also relevant to analyse (web pages of company sites, financial analysts' reports, press articles, etc.). However, researchers believe that the reference documents, due to their regularity and the rules to be respected in the drafting of this type of support, seem to be the most adequate sources of information to assess the level of disclosure on the IC in Jordan.

The third limitation concerns the measurement of the disclosure score on the IC. In this paper, researchers focused on the volume (quantity) of disclosure and not on its quality. It is recognised that the evaluation of the quality of disclosure is a complex subject that integrates other aspects of the company that go beyond the items identified in the IC analysis grid. To date, measuring the quality of voluntary disclosure remains an unresolved issue (Cerbioni and Parbonetti, 2007). The final limitation concerns the use of the word as a unit of analysis to assess the level of disclosure on the IC. This technique allowed researchers to quantitatively measure the importance of each item and therefore of each IC category in the annual report. However, this measure does not take into account the difference between qualitative (or narrative) and quantitative information. The calculation of a weighted score according to the nature of the information would be more relevant to assess the level of disclosure on the IC.

\section{References}

[1] ABDOLMOHAMMADI M.J. (2005), « Intellectual capital disclosure and market capitalization », Journal of Intellectual Capital, vol. 66, n $^{\circ}$ 3, pp. 397-416.

[2] ABDULRAHMAN A.O., Abdul HAMID F. (2012), « Extent and trend of intellectual capital reporting in Malaysia: empirical evidence », International Journal of Managerial and Financial Accounting, vol. 4, n 2, pp. 159-176.

[3] ABEYSEKERA I. (2010), « The influence of board size on intellectual capital disclosure by Kenyan listed firms », Journal of Intellectual Capital, vol. 11, $\mathrm{n}^{\circ}$ 4, pp. 504-518.

[4] ABOODY D., LEV B. (1998), « The value relevance of intangibles: The case of software capitalization », Journal of Accounting Research, vol. 36, pp. 161191.

[5] ALI A., CHEN T.-Y., Radhakrishnan S. (2007), « Corporate disclosures by family firms », Journal of Accounting and Economics, vol. 44, pp. 238-286.

[6] ANDERSON R.C., REEB D.M. (2003), « Founding-Family Ownership and Firm Performance: Evidence from the S\&P 500 », Journal of Finance, vol. 58, $\mathrm{n}^{\circ} 3, \mathrm{pp}$. 1301-1328.

[7] APRIL, K., BOSMA, P., DEGLON, D. (2003), « IC measurement and reporting: Establishing a practice in SA mining », Journal of Intellectual Capital, vol. $4, \mathrm{n}^{\circ} 2$, pp. 165-180.

[8] ASTRACHAN J.H., KOLENKO T.A. (1994), «A neglected factor explaining family business success: Human resources practices », Family Business Review, vol. 7, $\mathrm{n}^{\circ} 3$, pp. 75-87. 
[9] ASTRACHAN J.H., SHANKER M.C. (2003), « Family businesses' contribution to the U.S. economy: A closer look », Family Business Review, vol. 3, pp. 211219.

[10] BEATTIE V., THOMSON S.J. (2007), « Lifting the lid on the use of content analysis to investigate intellectual capital disclosures », Accounting Forum, vol. 31, pp. 129-163.

[11] BEATTIE V., MCINNES B., FEARNLEY S. (2002), Through the Eyes of Management: A Study of Narrative Disclosures, Institute of Chartered Accountants in England and Wales (ICAEW), Milton Keynes.

[12] BEAULIEU P., WILLIAMS S., WRIGHT M. (2002), « Intellectual capital disclosures in Swedish annual reports », in N. Bontis (dir.), World Congress on Intellectual Capital Readings, Oxford: Butterworth- Heinemann, pp. 135-156.

[13] BONTIS N. (2003), «Intellectual Capital Disclosure in Canadian Corporations », Journal of Human Resource Costing and Accounting, vol. 7, $\mathrm{n}^{\circ}$ 1-2, pp. 9-20.

[14] BOZZOLAN S., FAVOTTO F., RICCERI F. (2003), « Italian annual intellectual capital disclosure », Journal of Intellectual Capital, vol. 4, $\mathrm{n}^{\circ}$ 4, pp. 543-558.

[15] BOZZOLAN S., O'REGAN P., RICCERI F. (2006), «Intellectual capital disclosure (ICD), A comparison of Italy and the UK », Journal of Human Resource Costing and Accounting, vol. 10, $\mathrm{n}^{\circ}$ 2, pp. 92-113.

[16] BRENNAN N. (2001), « Reporting intellectual capital in annual reports: evidence from Ireland », Accounting, Auditing \& Accountability journal, vol. $14, \mathrm{n}^{\circ} 1$, pp. 423-436.

[17] BROOKING, A. (1997), Intellectual Capital, London: International Thomson Business Press.

[18] BRÜGGEN A., VERGAUWEN P., DAO M. (2009), « Determinants of intellectual capital disclosure: evidence from Australia », Management Decision, vol. 47, $\mathrm{n}^{\circ}$ 2, pp. 233-245.

[19] BUKH P.N., JOHANSON U. (2003), « Research and knowledge interactions: Guidelines for IC reporting », Journal of Intellectual Capital, vol. $4, \mathrm{n}^{\circ} 4$, pp. 576587.

[20] CAMPBELL D.J. (2000), « Legitimacy theory or managerial reality construction? Corporate social disclosure in Marks and Spencer Plc corporate reports, 1969-1997 », Accounting Forum, vol. 24, $\mathrm{n}^{\circ}$ 1, pp. 80-100.

[21] CAMPBELL D.J., ABDUL RAHMAN M.R. (2010), « A longitudinal examination of intellectual capital reporting in Marks \& Spencer annual reports, 1978-2008 », The British Accounting Review, vol. 42, $\mathrm{n}^{\circ} 1$, pp. 56-70.

[22] CARNEY M. (2005), « Corporate Governance and Competitive Advantage in Family-Controlled Firms », Entrepreneurship Theory and Practice, vol. 29, n³, pp. 249-265,

[23] CASTILLO J., WAKEFIELD M.W. (2007), « An exploration of firm performance factors in family businesses: do families value only the "bottom line"? », Journal of Small Business Strategy, vol. 17, $\mathrm{n}^{\circ} 2$, pp. 37-51.

[24] CERBIONI F., PARBONETTI A. (2007), « Exploring the effects of corporate governance on intellectual capital: An analysis of European Biotechnology Companies », European Accounting Review, vol. 16, $\mathrm{n}^{\circ}$ 4, pp. 791-826.

[25] CHAMINADE C., ROBERTS H., (2003), «What it means is what it does: a comparative analysis of implementing intellectual capital in Norway and Spain », European Accounting Review, vol. 12, $\mathrm{n}^{\circ}$ 4, pp. 733-751.

[26] CHANG C.H., CHEN Y.S. (2012), « The determinants of green intellectual capital », 
Management Decision, vol. 50, $\mathrm{n}^{\circ} 1, \mathrm{pp}$. 74-94.

[27] CHAU G., GRAY S.J. (2010), « Family ownership, board independence and voluntary disclosure: Evidence from Hong Kong », Journal of International Accounting, Auditing and Taxation, vol. 19, pp. 93-109.

[28] CHEN S., CHEN X., CHENG Q. (2008), « Do Family Firms Provide More or Less Voluntary Disclosure? », Journal of Accounting Research, vol. 46, $\mathrm{n}^{\circ} 3$, pp. 499-536.

[29] CHRISMAN J., CHUA J., LITZ R. (2003), «A unified perspective of family firm performance: An extension and integration ", Journal of Business Venturing, vol. 18, ${ }^{\circ}$ 4, pp. 467-472.

[30] CHUA J.H., CHRISMAN J.J., STEIER L. (2003), « Extending the Theoretical Horizons of Family Business Research », Entrepreneurship, Theory and Practice, vol. 29, pp. 331-338.

[31] DEBICKI B.J., MATHERNE C.F., KELLERMANS F.W., CHRISMAN J.J. (2009), «Family Business Research in the New Millennium: An Overview of the Who, the Where, the What, and the Why », Family Business Review, vol. 22, ${ }^{\circ} 2$, pp. 151-166.

[32] DIAMOND D.W., VERRECCHIA R.E. (1991), «Disclosure, liquidity and the cost of capital », Journal of Finance, vol. 46, $\mathrm{n}^{\circ}$ 4, pp. 1325-1135.

[33] EDVINSSON L. (1997), « Developing intellectual capital at Skandia », Long Range Planning, vol. 30, $\mathrm{n}^{\circ} 3$, pp. 366373.

[34] EDVINSON L., MALONE M. (1997), Intellectual Capital Realizing Your Company's True Value by Finding its Hidden Brainpower, New York: Harper Collins Publishers.

[35] GARCIA-MECA E., PARRA I., LARRAN M., MARTINEZ, I. (2005), « the explanatory factors of intellectual capital disclosure to financial analysts », European Accounting Review, vol. 14, $\mathrm{n}^{\circ}$ 1, pp. 63-94.

[36] GOH P.C., LIM K.P. (2004), « Disclosing intellectual capital in company annual reports: Evidence from Malaysia », Journal of Intellectual Capital, vol. 5, $\mathrm{n}^{\circ} 3$, pp. 500-510.

[37] GUL F. A., LEUNG S. (2004), « Board leadership, outside directors' expertise and voluntary corporate disclosures », Journal of Accounting and Public Policy, vol. 23, $\mathrm{n}^{\circ}$ 5, pp. 351-379.

[38] GUTHRIE J., PETTY R. (2000), « Intellectual capital: Australian annual reporting practices », Journal of Intellectual Capital, vol. 1, n 3, pp. 241251.

[39] GUTHRIE J., PETTY R., YONGVANICH K., RICCERI F. (2004), «Using content analysis as a research method to inquire into intellectual capital reporting », Journal of Intellectual Capital, vol. 5, $\mathrm{n}^{\circ} 2$, pp. 282-293.

[40] GUTHRIE J. PETTY R., RICCERI F. (2006), « The voluntary reporting of intellectual capital: comparing evidence from Hong-Kong and Australia », Journal of Intellectual Capital, vol. 7, $\mathrm{n}^{\circ}$ 2, pp. 254-271.

[41] HABERSAM M., PIBER M. (2003), « Exploring Intellectual Capital in Hospitals - two qualitative case studies in Italy and Austria », European Accounting Review, vol. 12, n 4, pp. 753-779.

[42] HACKSTON D., MILNE M. (1996), « Some determinants of social and environmental disclosures in New Zealand companies », Accounting, Auditing and Accountability Journal, vol. 9, $\mathrm{n}^{\circ}$ 1, pp. 77-108.

[43] HARRIS R.D., REID R.S., MCADAM R. (2004), «Consultation and communication in family businesses in Great Britain », 
The International Journal of Human Resource Management, vol. 15, $\mathrm{n}^{\circ}$ 8, pp. 1424-1444.

[44] HAYES R.M., SCHAEFER S. (1999), « How Much Are Differences in Managerial Ability Worth? », Journal of Accounting and Economics, vol. 27, pp. 125-148.

[45] HIDALGO R.L., GARCIA-MECA E., MARTINEZ I. (2011), « Governance and intellectual capital disclosure », Journal of Business Ethics, n 100, pp. 483-495.

[46] HO S., WONG K.S. (2001), « A study of the relationship between corporate governance structures and the extent of voluntary disclosure », Journal of International Accounting, Auditing and Taxation, vol. 10, pp. 139-156.

[47] HOLLAND J. (2001), « Financial institutions, intangibles and corporate governance », Accounting, Auditing \& Accountability Journal, vol. 14, $\mathrm{n}^{\circ} 4$, pp. 497-529.

[48] HOLLAND J. (2006), « Fund Management, Intellectual Capital, Intangibles and Private Disclosure », Managerial Finance, vol. 32, $n^{\circ}$ 4, pp. 277 316.

[49] ITAMI H. (1989), « Mobilising invisible assets: the key for successful corporate strategy », in E. Punset, G. Sweeny (dir.), Information Resources and Corporate Growth, Pinter Publishers.

[50] JENSEN M.C., MECKLING W.H. (1976), « Theory of the Firm: Managerial Behavior, Agency Costs and Ownership Structure », Journal of Financial Economics, vol. 3, pp. 305-360.

[51] LEV B. (1992), «Information Disclosure Strategy », California Management Review, vol. 34, $\mathrm{n}^{\circ}$ 4, pp. 9-32. LEV B. (2001), Intangibles: Management, measurement, and reporting. New York, NY: Brookings Institution Press.

[52] LEV B., ZAMBON S. (2003), « Introduction to the special issue »,
European Accounting Review, vol. 12, $\mathrm{n}^{\circ}$ 4, pp. 597-603.

[53] LI J., PIKE R., HANIFFA R. (2008), « Intellectual capital disclosure and corporate governance structure in UK firms », Accounting and Business Research, vol. 38, n 2, pp. 137-159.

[54] LI J., MANGENA M., PIKE R. (2012), « The Effect of Audit Committee Characteristics on Intellectual Capital Disclosure », British Accounting Review, vol. 44, $\mathrm{n}^{\circ} 2$, pp. 98-110.

[55] MEEK G.K., ROBERTS C.B., GRAY S. J. (1995), « Factors influencing voluntary annual report disclosure by U.S., U.K. and Continental European multinational corporations », Journal of International Business Studies, vol. 26, $\mathrm{n}^{\circ} 3$, pp. 555572.

[56] MOURITSEN J., LARSEN H.T., BUKH P.N.D. (2001), « Intellectual capital and the 'capable firm': narrating, visualizing and numbering for managing knowledge, Accounting, Organizations and Society, vol. $26, \mathrm{n}^{\circ}$ 7-8, pp. 735-762.

[57] MILLER D., LE BRETON-MILLER I., SCHOLNICK B. (2008), « Stewardship vs Stagnation: An Empirical Comparison of Small Family and Non-Family Businesses », Journal of Management Studies, vol. 45, $\mathrm{n}^{\circ} 1$, pp. 51-78.

[58] OLIVEIRA L., RODRIGUES L.L., CRAIG R. (2006), « Firm-specific determinants of intangibles reporting: evidence from the Portuguese stock market », Journal of Human Resource Costing and Accounting, vol. 10, $\mathrm{n}^{\circ}$ 1, pp. 11-33.

[59] RAMEZAN M. (2011), « Intellectual capital and organizational organic structure in knowledge society: How are these concepts related? », International Journal of Information Management, vol. 31, pp. 88-95.

[60] RICCERI F., GUTHRIE J. (2009), « Critical analysis of international guidelines 
for the management of knowledge resources », in D. Jemielniak, J. Kociatkiewicz (dir.), Handbook on research on knowledge intensive organisations. PA: Information Science Press.

[61] RYLANDER A., JACOBSEN K., ROOS G. (2000), « Towards improved information disclosure on intellectual capital », International Journal of Technology Management, vol. 20, pp. 715-42.

[62] SALVATO C., MOORES K. (2010), « Research on Accounting in Family Firms: Past Accomplishments and Future Challenges », Family Business Review, vol. 23, n 3, pp. 193-215.

[63] SHARABATI A.A., JAWAD S.N., BONTIS N. (2010), « Intellectual capital and business performance in the pharmaceutical sector of Jordan », Management Decision, vol. 48, $\mathrm{n}^{\circ} 1, \mathrm{pp}$. 105-131.

[64] STEWART T.A. (1997), Intellectual capital: the new wealth of organizations, Crown Business.

[65] STRIUKOVA L., UNERMAN J., GUTHRIE J. (2008), « Corporate reporting of intellectual capital: Evidence from UK companies », The British Accounting Review, vol. 40, pp. 297-313.

[66] WESTHEAD P, HOWORTH C. (2006), « Ownership and Management Issues Associated With Family Firm Performance and Company Objectives », Family Business Review, vol. 19, $\mathrm{n}^{\circ}$ 4, pp. 301 316.

[67] WEXLER M.N. (2002), « Organizational memory and intellectual capital », Journal of Intellectual Capital, vol. 3, $\mathrm{n}^{\circ}$ 4, $\mathrm{pp}$. 393-414.

[68] WHITE G., LEE A., TOWER G. (2007), « Drivers of voluntary intellectual capital disclosure in listed biotechnology companies », Journal of Intellectual Capital, vol. 8, $\mathrm{n}^{\circ} 3$, pp. 517-537.

[69] WHITING R.H., MILLER J.C. (2008), « Voluntary disclosure of intellectual capital in New Zealand annual reports and the "hidden value" », Journal of Human Resource Costing and Accounting, vol. 12, $\mathrm{n}^{\circ} 1$, pp. 26-50.

[70] WHITING R.W., WOODCOCK J. (2011), «Firm characteristics and intellectual capital disclosure by Australian companies », Journal of Human Resource Costing and Accounting, vol. 15, $\mathrm{n}^{\circ}$ 2, pp. 102-126.

[71] WILLIAMS S. M. (2001), «Is intellectual capital performance and disclosure practices related? », Journal of Intellectual Capital, vol. 2, $\mathrm{n}^{\circ}$ 3, pp. 192-203.

[72] YANG C., LIN C. (2009), « Does intellectual capital mediate the relationship between HRM and organizational performance? Perspective of a healthcare industry in Taiwan », The International Journal of Human Resource Management, vol. 20, n 9, pp. 1965-1984.

[73] YAU F.S., CHUN L.S., BALARAMAN R. (2009), « Intellectual capital reporting and corporate characteristics of publiclisted companies in Malaysia », Journal of Financial Reporting \& Accounting, vol. 7, $\mathrm{n}^{\circ} 1$, pp. 17-35.

[74] Nahed Habis Alrawashedh, "The application of human resource accounting systems in public shareholding companies in Jordan" International Journal of Psychosocial Rehabilitation, Vol. 24, Issue 08, 2020, ISSN: 1475-7192. 